\title{
STEAM Education for Critical Consciousness: Discourses of Liberation and Social Change among Sixth-Grade Students
}

\author{
Bhaskar Upadhyay | ORCID: 0000-0001-5141-3778 \\ Corresponding author, \\ Department of Curriculum and Instruction, University of Minnesota, \\ 125 Peik Hall, Minneapolis, MN 55455, USA \\ bhaskar@umn.edu
}

\author{
Kara Coffino \\ School of Education, Colorado State University, Education Building, \\ 450 W Pitkin St., 1588 Campus Delivery, Fort Collins, CO 80523-1588, USA \\ Kara.Coffino@colostate.edu
}

\author{
John Alberts \\ Austin Independent School District, Austin, P.o. Box 878, Austin, \\ MN 55912, USA \\ john.alberts@austin.k12.mn.us
}

\author{
Andrew Rummel | ORCID: 0000-0003-4357-5931 \\ Department of Curriculum and Instruction, University of Minnesota, \\ 125 Peik Hall, Minneapolis, MN 55455, USA \\ rummoon@umn.edu
}

Received: 1 March 2021 | Revised: 16 April 2021 | Accepted: 1 May 2021

\begin{abstract}
In this case study, we present opportunities science, technology, engineering, arts, and mathematics (STEAM) education provided to a sixth-grade class. We collected observational and interview data in a language arts and a science class over 1 year. We used the liberation social psychology (LSP) framework to understand students' discourses and discussions as they drew from science, engineering activities, and language arts ideas. Further, LSP allowed us to explore students' engagement in critical reflection of


social, racial, and other discrimination. The data analysis showed that STEAM education promoted the integration of science ideas, engineering design, social and critical consciousness. We found STEAM education supported discourses of critical reflection, racism, and social discrimination in class. Finally, we argue that STEAM education in Asia-Pacific and Global South countries has to be about critical consciousness, social change, and liberation of underrepresented groups and immigrants for more inclusive, sociopolitically conscious, and democratic STEAM education experiences.

\section{Keywords}

STEAM education - critical consciousness - middle school - social change - liberation social psychology - cultural context

\section{Introduction}

Science, technology, engineering, and mathematics (sтеM) education has gained popularity in K-12 educational spaces because it helps prepare youths to excel in the 21st-century economy. STEM education policymakers and advocates believe in teaching students STEM-related skills in STEM education classrooms (Bybee, 2010; National Research Council, 2013). Additionally, STEM education in K-12 settings has been promoted as the path to gain economic, scientific, engineering, and technological success both at the personal level and the global level (e.g., Belbase, 2019; Kelley \& Knowles, 2016; National Research Council, 2013). Much research related to K-12 STEM education has focused on the cognitive aspects of STEM; an integrated approach to learning one of the STEM fields engenders academic success (National Academy of Engineering and National Research Council, 2014; National Science Board, 2010) and greater proficiency with sTEM-related practices and skills (Organisation for Economic Co-operation and Development, 2016). Additionally, some research has shown that STEM education promotes motivation to engage in and pursue a STEM-related field (Means et al., 2016) and builds a greater association with the STEM fields through an integrated approach to teaching science (Eisenhart et al., 2015). Finally, some science education scholars have advocated for STEM as an integrated approach to teaching through conceiving and solving authentic problems (Hallström \& Ankiewicz, 2019).

However, limited research has explored STEM teaching and learning in the context of marginalized youths, communities, and schools in K-12 settings. Some researchers, such as Calabrese Barton et al. (2011) and Carlone and 
Johnson (2012), have started to investigate issues of agency, empowerment, gender identities, and racial biases that students experience and engage with in K-12 STEM classroom contexts. A large majority of sTEM education research has taken place around the issues of curriculum development and pedagogy, mostly focused on building 21st-century skills (e.g., Kelley \& Knowles, 2016; Radloff \& Guzey, 2016) but without critically examining the issues of equity, social justice, agency, and social change.

Conversely, many K-12 schools have added language arts or arts to STEM to make it STEAM for local political reasons and to ensure that essential learning areas such as language, social studies, and arts are not left out. In some schools, becoming a STEAM school is deliberate. These school leaders and teachers want to bring social change, communication, immigration, human migration, politics, power, and equity to enrich their students' experiences (Upadhyay et al., 2021b). Therefore, this paper adds to the literature and research conversations exploring equity, social justice, empowerment, and critical consciousness issues. We specifically focus on one sixth-grade STEAM school class where students and teachers draw their teaching and learning from the school's STEAM framework (see Upadhyay et al., 2021b). This paper provides a snapshot of how to provide space for students to explore structural issues, social and political inequities, and social change issues in the contexts of learning science, engineering, and language arts and literature. In our view, the field of STEM education would benefit from the theoretical frameworks of critical consciousness (Freire, 1972; Ladson-Billings, 1995) and liberation social psychology (LSP; Martín-Baró, 1996). We use critical consciousness and LSP to understand better how a STEAM classroom setting provided space for sixth-grade students to participate in the social and political analysis of contextual social and political challenges utilizing STEM ideas and activities.

In this paper, we first describe the theories of critical consciousness and LSP. We then discuss oppression and diversity in K-12 science and STEM education. We provide the methodology and data collection followed by a brief analytical process. Our findings are followed by discussions and implications of this study in STEAM education broadly, including Asian regions.

\section{Theoretical Framework}

\subsection{Liberation Social Psychology (LSP)}

In this paper, we draw from the idea of LSP as a robust theoretical framework to understand how STEAM education could be a space for making sense of the issues of oppression, societal structures that perpetuate inequity, and 
oppressive values and beliefs (Martín-Baró, 1994). Martín-Baró (1994), a Jesuit priest, proposed the idea of LSP as Latin American psychology to support marginalized and oppressed people to overcome their lived trauma and to empower them by incorporating their own lived experiences. LSP recognizes the detrimental effects of social injustices, repression, discrimination, and poverty levied on marginalized people by dominant power structures. This recognition engenders LSP to generate a dialogic environment that values oppressed people's voices, allows for critical reflection of the experiences of oppressions, and encourages actions for social change (Martín-Baró, 1994). Thus the end goal of LSP is to empower the oppressed people to liberate themselves from oppressive dominant power by understanding their marginalization and taking actions towards building a more supportive structure of power for the marginalized groups (Martín-Baró, 1994; Montero, 1996). Therefore, LSP is about social transformation (Burton \& Kagan, 2005) and personal change. We first describe the core ideas of LSP and then discuss how this framework allows us to understand sixth-grade students' engagement in STEAM learning and STEAM-related activities for critical consciousness, social transformation, and empowerment.

\section{$2.2 \quad$ Core Ideas of LSP}

LSP has three major elements focused on the dialogic interactions between the agents or actors who work towards empowering the oppressed groups and the oppressed people's lived experiences (Burton \& Kagan, 2005; Martín-Baró, 1996; Montero, 1996; Watts et al., 2003). Three components are (a) conscientization or critical consciousness; (b) realismo crítico or critical realism; and (c) de-ideologization (Martín-Baró, 1996). We describe each component and how they allow us to understand sixth-grade students' discussions of STEAM activities, generating critical reflections about social oppression, immigration, and a sense of empowered (agentic) individuals.

\subsection{Conscientization or Critical Consciousness}

LSP rests on the idea that liberation from any oppressed system or any individual is a process of recognizing the roots of oppression and taking actions to make a change (Freire, 1972). When marginalized people are given opportunities and tools to reflect on their experiences, they can locate, understand, and take action for social change (Freire, 1972; Ladson-Billings, 1995, 2014; Upadhyay et al., 2020, 2021a). The idea of critical consciousness is based on the underlying assertion that human beings are capable of transforming and understanding their social reality (Watts et al., 2003) by engaging in critical reflections and actions associated with oppression and marginalization. Additionally, for 
critical reflections to occur, individuals need to engage in a dialogic environment to deconstruct and unearth both evident and hidden natures of oppression and marginalization (Bruna, 2009; Upadhyay et al., 2020). Drawing from many scholars' works (Freire, 1972; Kincheloe, 1999; Kincheloe \& Steinberg, 1993; Ladson-Billings, 1995; Martín-Baró, 1986; Watts et al., 2003), we conceptualize critical consciousness as awareness of both the histories and the processes of oppressions that marginalized groups and individuals endure in society.

In the context of STEM or STEAM teaching and learning, teachers hardly engage students in the process of critical consciousness (e.g., Upadhyay et al., $2020,2021 b)$. Most of the reported studies on STEAM education have relied on learning about science and engineering practices, problem solving, and exploring the value of integrating content areas for learning (Kelley \& Knowles, 2016; Lynn et al., 2016; Vasquez et al., 2013). Studies that explored critical consciousness in STEM education are mostly from science and mathematics education fields, not from STEAM education (Jennings \& Eichinger, 1999; Upadhyay et al., 2020). Therefore, an urgent need exists to understand how STEAM teaching and learning could enhance and support critically conscious activities and discourses in class. The idea of critical consciousness helped us understand how a sixth-grade STEAM school classroom provided a suitable environment to engage students in critically conscious activities and experience a socially transformative experience. Further, critical consciousness allowed us to understand how students saw themselves as agents of social change and liberation.

\subsection{Realismo Crítico or Critical Realism}

In the context of LSP, we understand realismo crítico or critical realism as the idea that local issues of oppression and discrimination have locally suitable solutions (Martín-Baró, 1996). Critical realism thus engages people in ideas and theories appropriate to understand in the local context and generate locally practical outcomes (Burton \& Kagan, 2005). Reality-based and critically defined problems can provide solutions to local sociocultural and sociohistorical issues benefiting local oppressed communities. In STEAM education, the focus is on engaging students in local issues for the basis of STEAM activities. Local issue-based problems create opportunities to critique, challenge, and redefine problems and potential solutions that are more socially just and empowering to marginalized students. The focus on local issues also helps students and teachers draw from students' home experiences to examine the causes and effects of oppression, injustices, and inequities. Thus, students receive opportunities for social change and personal transformation through STEAM engagement. We caution STEAM teachers, educators, researchers, and curriculum developers not to stereotype and stigmatize local problems or 
contexts, in the name of authentic problems, used in STEAM activities, specifically engineering design activities, to only marginalized, impoverished, and Global South communities. Many of these same local problems could also be in affluent and dominant group communities. Therefore, realismo critico is about the critical examination of how, where, and in what ways local problems are situated in the histories, policies, cultures, and economies of marginalization.

\subsection{De-Ideologization}

We view ideology as a lens through which an individual has to view the world based on their values, beliefs, assumptions, history, and expectations. Every individual, community, and group has an ideology. This results in ideological dissonance between dominant groups and oppressed groups. Therefore, ideology has consequences (Cole, 2020), and it is political, not epistemic (Sypnowich, 2019). Ideology obscures the realities of other people and prevents them from influencing dominant views, thus creating a closed system. According to Eagleton (1991, as cited in Cole, 2019),

Ideology is a system of concepts and views which serves to make sense of the world while obscuring the social interests that are expressed therein, and by its completeness and relative internal consistency tends to form a closed system and maintain itself in the face of contradictory or inconsistent experience. (para. 6)

Therefore, in LSP, the idea of de-ideologization is vital to allow for questioning and challenging the status quo rooted in stereotypes and dominant group values, beliefs, and assumptions (Martín-Baró, 1996). Recognizing and pushing back on stereotypes perpetuated and held about marginalized groups create a more agentic environment in which marginalized groups are seen possessing skills and attitudes for success. LSP advocates that people in positions of power need to accept the social contexts (realities) of oppressed groups as legitimate. Ignoring oppressed people's social contexts promotes the dominant ideology, creating a mismatch between how oppressed people experience social reality and that of the dominant group. In this paper, we draw from this idea to understand and explore how students in a STEAM classroom attempt to disrupt the narratives of immigration, immigrants, and racial discrimination utilizing content from STEAM fields.

We are not interested in creating psychopathological analyses or categories. We are interested in using the ideas of LSP to explore and understand how students engage in critical reflections and activities for critical consciousness. Additionally, we seek to know how students create and experience a sense of 
agency and empowerment when they get opportunities to explore and link their understandings of discrimination, neglect, marginalization, and oppression in STEAM activities and learning contexts.

\subsection{Liberation and Science Education}

Many scholars focused on equity and social justice in science education have advocated for science education that engages and builds students' liberatory attitudes and actions (Calabrese Barton et al., 2011; Jennings \& Eichinger, 1999; Osborne \& Calabrese Barton, 1998; Upadhyay, 2012; Upadhyay \& Albrecht, 2011; Upadhyay et al. 2020). Several scholars and philosophers have viewed education's liberatory power for the oppressed, but they also cautioned that education could promote the dominant group's cultural hegemony (Fanon, 2005; Freire, 1972; Gramsci, 1971). The idea of liberation in science education is to

allow the science activities that the [students] do emerge from the intersections of the social, historical, political, and physical contexts of [their] lives and, through conversation and action, come to construct meaning about science, self, and the relationships between science, self, and community.

CALABRESE-BARTON, 1998, p. 297

Therefore, science education for liberation is about how science is locally defined and situated in students' lives defined by their personal, social, cultural, and historical events and boundaries. When science is local, students can engage in oppositional consciousness, where the value of learning science intersects with local sociocultural and sociopolitical issues (Sandoval, 1995). Similarly, for STEAM education to promote social change and critical consciousness, it is always situated in the local community and contemporary sociocultural issues. STEAM education, including authentic experiences related to STEAM fields, can leverage science contents supporting students to critically explore sociocultural and sociopolitical issues that they encounter in the community.

\section{$3 \quad$ Research Questions}

1. How does steam education build critical consciousness and empowerment in sixth-grade students?

2. How do students leverage STEAM ideas for liberatory and transformative engagement? 
This paper is a case study of one sixth-grade class in a STEAM middle school. There are three approaches to the case study method based on the nature of the research (Merriam, 1998; Stake, 1995; Yin, 2002). We chose a constructivist approach to case study methodology based on Merriam (1998) because it allowed us to document, interrogate, and understand STEAM education's possibilities and complexities as students engaged in various activities and discussions. Merriam's approach values that "reality is constructed by individuals interacting with their social worlds" (Merriam, 1998, p. 6), aligning with the LSP framework. Additionally, this approach to case study fits our questions because our goal was to understand and document how students found linkages between STEM knowledge and aiding them to construct meanings and relationships emerging from social and political issues. We believed that a constructivist case study facilitated our attempt to locate students' interactions in "culturally derived and historically situated interpretations of [their personal] social life-world" and STEAM engagement (Crotty, 1998, p. 67).

Constructivist case study enabled us to explore in an in-depth and holistic way (Merriam, 2002) how and why participants engaged and made meaning from complex social and political issues in STEAM education contexts. The constructivist case study method also supported our goal to explore how students engaged in STEAM classrooms and used STEAM contents in sociocultural and sociohistorical discussions. We also found opportunities to observe, participate in informal conversations, and locate discourses and actions showing critical consciousness, empowerment, liberatory interactions, and personal transformation points among students. The case study also provided us with moments when we observed intricate and nuanced interactions filled with deeply personal and social critiques. We utilized classroom observations, short informal conversations, field notes, and student/teacher artifacts to collect data. In this paper, we mostly focus on what students did, said, and engaged in, but we intersperse that with teacher actions to provide contexts to help readers better understand the findings.

\subsection{University-School Partnership}

This paper is based on a two-year partnership between a research university and a school district in a US Midwestern State (for detail of the partnership, see Upadhyay et al., 2021). The goal of the partnership was to prepare $5^{\text {th }}$ and 6th grade teachers to gain ideas, theories, and pedagogical skills to be STEAM education teachers. In Year 1, teachers and leaders participated in monthly professional development workshops led by the university faculty team. A 
key goal in Year 1 was redesigning a curriculum that deliberately integrated language arts in ST EM areas. During this process, language arts teachers suggested several books that could crosscut between STEM contents. The teachers decided on 'Dragonwings' (Yep, 2003), a book integrated with windmill design activity as a part of integrated STEAM content.

In Year 2, the university faculty supported teachers in the implementation of the new STEAM curriculum, pedagogy, and assessment through regular classroom observations, after-school workshops, and debriefing sessions after classroom observations. The first STEAM topic in Year 2 was on designing a windmill, learning about materials science, energy transformation, and integrating it with social, immigration, race, and economic issues raised in Dragonwings. The students designed windmills in science class, and in language arts class, they studied Dragonwings. This kind of curricular design provided students and teachers spaces to draw from each area and related activities for a meaningful STEAM learning environment.

\subsection{Classroom Context}

This study is based on one section of sixth-grade class in a STEAM school. The language arts teacher is Mrs. B, who teaches the English language. She started with the historical fiction book titled Dragonwings as part of their literary discussion. Mrs. B's class was inquiry-based with a focus on student discussions. She would give discussion questions and prompts such as "How do you see Moon Shadow in light of young struggling immigrant youth?"; "Why do Chinese immigrants see White Americans as untrustworthy?" and "What kind of relationship do you see between what you are making in STEM class and what the Windrider was making?" Similarly, in one class, she asked students to create a relational graphic that showed complex social issues based on the book and the current social problems in their community with immigrants. Students in groups then presented their work to the whole class for further discussions.

Mrs. H's science class followed inquiry-based hands-on instruction. Before students started the Windmill design, they engaged in learning about the transformation of energy, specifically potential to kinetic to mechanical. Students received a task to figure out if a "ball bearing dropped from a height would dent (make a mark) on a soft clay." The students were first asked to predict and then test their predictions in groups. Mrs. $\mathrm{H}$ asked the groups to discuss "if a heavier ball bearing would make a bigger or deeper dent in a soft clay compared to a lighter one." After the discussion, students tested their predictions with two different weight ball bearings. This activity provided students to understand the concepts of potential and kinetic energy and how the energy was related 
to the weight (mass) of the ball bearing. Students would later use this idea of energy in designing and building a workable windmill. Mrs. $\mathrm{H}$ told the class that she would want them also ask how their windmill design and construction would help answer some of the challenges of energy, pollution, access to clean energy based on race and income, and who could afford to buy this kind of energy.

Both Mrs. B and Mrs. H believed in inquiry-based teaching, where students would get opportunities for discourses and experimentations. The teachers would provide prompts to build on previous ideas that students had learned with more time spent on discussions and group activities. Therefore, these classrooms provided us with ideal environments to understand how students engaged in STEAM classroom activities and connected them to explore local sociopolitical, social justice, race, and other discriminatory issues.

\subsection{Observations}

We collected observation data in Year 2 of the partnership when teachers implemented the STEAM curriculum in the sixth-grade program. We followed several sixth-grade sections, but we only focus on one sixth-grade class section for this paper. We chose this class for several reasons: (i) racially more diverse students (an African American, four Hispanic, two Hmong, one Sudanese); (ii) willingness among students to bring diverse racial experiences; (iii) greater connections to experiences of challenges to being an immigrant, refugee, and underrepresented group; and (iv) actively drawing from Dragonwings readings, science, engineering, and windmill design activities. Most of the sixthgrade sections were about $24-26$ students. Additionally, the students in this class showed active engagement in discussions and activities. Most of them took critical views on sociocultural, immigration, sociohistorical, and STEM ideas. For example, we observed students discussing how their immigrant peers encountered challenges such as language, food, access to health services, and how the White peers did not have to worry about those issues.

They were also reflective of their positionality in the community. For example, Hispanic, Somali, and Hmong students shared how they had to be translators for their parents and elders and not find culturally familiar foods. We collected data over four classroom observations in an English language arts class and four observations in a science class. During the observations, we focused on several important aspects of STEAM education to understand how students engaged in activities and discussions that critically reflected on sociocultural, sociopolitical, and historical issues. We were keen on classroom activities and discussions related to science, engineering, and mathematics that students connected to economics, immigration, culture, and politics (see 
TABLE 1 Topics covered during a STEAM class

\begin{tabular}{|c|c|c|}
\hline Topic & Science & English language arts \\
\hline Windmill & Energy & $\begin{array}{l}\text { Arguments, synthesis, text } \\
\text { analysis, politics, race } \\
\text { Book: Dragonwings }^{\mathrm{a}}\end{array}$ \\
\hline Designing windmill & $\begin{array}{l}\text { Rotor blades, the strength of } \\
\text { rotor materials, wind speed }\end{array}$ & $\begin{array}{l}\text { Wings: object and } \\
\text { symbolism (immigration), } \\
\text { struggle, resiliency }\end{array}$ \\
\hline Design tests & Cost of materials and design & Economic impact on family \\
\hline Trial and error & $\begin{array}{l}\text { Cost to install, geographical } \\
\text { constraints, redesign, } \\
\text { adjustments in design/ } \\
\text { function }\end{array}$ & $\begin{array}{l}\text { Economic constraints, } \\
\text { social constraints, language } \\
\text { constraints }\end{array}$ \\
\hline Social and historical & $\begin{array}{l}\text { Who gets the benefit? Native } \\
\text { land, climate change, fossil } \\
\text { fuel, renewable energy }\end{array}$ & $\begin{array}{l}\text { Discrimination against } \\
\text { Asian immigrants (Chinese } \\
\text { specifically), race, language } \\
\text { barriers, social barriers, } \\
\text { resiliency, Wright brothers }\end{array}$ \\
\hline
\end{tabular}

a Dragonwings (25th ed.), by L. Yep, 2003, Harper Collins.

Table 1 for content coverage). During this time, the politics and the discourses of immigration, immigrants, and refugees were all over the US news and social media. Therefore many students' had heightened sensibilities and awareness about these issues. The observations lasted between 30-40 minutes each time over 3 months during various stages of the STEAM lessons and activities on windmill design and the book Dragonwings.

\section{$5 \quad$ Synopsis of Dragonwings}

Dragonwings is a historical fiction that provides a window into Chinese immigrant life in the San Francisco area in the early part of 190o. The story is about a father, Windrider, and his son, Moon Shadow, living in the city with racial prejudice and discrimination against Chinese immigrants. The story captures the financial, linguistic, racial, economic, and familial struggles of Windrider to make a pair of wings out of cloth so he could fly just like he did in his homeland 
in China. However, the story's central plot is how Moon Shadow wants to make his father's dream to fly a reality despite racial discrimination against Chinese immigrants, financial hardships to support a family back home, and perseverance regardless of multiple design failures. The 1906 San Francisco earthquake could have derailed Windrider's dream to fly, but Moon Shadow and Windrider both endured racial and xenophobic challenges and made the dream to fly come true.

\subsection{Informal Conversations}

The first author had 25-30 informal conversations with students and the teachers during class activities and group discussions. These conversations mostly lasted for $5^{-10}$ minutes. The questions posed for further elaboration included the following:

- "How do you see social prejudices Moon Shadow, Windrider, and other Chinese immigrants faced then and now (Hispanic, Hmong, Sudanese/ Karen) in your community?"

- "What makes Windrider's wing design experience different and similar from yours in this class?"

- "Why do you find making a windmill an important activity?"

- "How did you decide that a windmill could be a good renewable source of energy for your area?"

- "Based on the Dragonwings book that you are reading in Mrs. B's class and the windmill design you are doing here, what connections do you see between them?"

With teachers, we asked the following:

- "What made you choose this activity/book for STEAM education?"

- "How did you decide critical reflection was an essential part of STEAM teaching and learning?"

- "What are some of the opportunities and challenges of engaging students in social, political/immigration, cultural, and racial issues in STEAM teaching and learning?"

We collected this information as audio recordings or field notes.

\section{2 $\quad$ Field Notes}

The field notes were collections of reflections of classroom observations, the researchers' opinions, reflective notes, and descriptions of student-teacher and student-student interactions on social, cultural, racial, immigration, and language issues supported and complicated by mostly ideas from science but at times from technology and mathematics. Engineering activities came into play in these conversations when learning about designing objects and building engineering and science skills. Sociocultural and sociohistorical issues 
became part of the classroom discourses in engineering design activities when teachers intentionally helped students connect the activities to the book (Dragonwings) they were reading in the language arts class. The field notes were an excellent way for us to rethink researcher positionalities and the partnership's future direction to support teacher development and student success as critical thinkers of social change and personal transformation.

\subsection{Context of the STEAM School}

The school is located in a rural town in the Midwestern United States. The school focuses on integrating and leveraging various local and school resources to make learning more culturally relevant and STEAM-oriented. Teachers collaborated to find activities, books, and content to allow for an authentic experience by integrating language arts and social studies with STEM disciplines. Mrs. B suggested the Dragonwings book during the professional development workshop a year earlier. During the same workshop, teacher leaders decided which engineering activities sixth-grade students would do. The local community had a large windmill farm, so teachers agreed that a windmill design activity would be locally relevant. Thus the science topics on energy, material, and motion would connect with mathematics ideas of proportion. Students would learn about various tools and materials such as plastic straw and cutting tools in the area of technology and that every technology has side effects or unintended consequences. On the engineering side, teachers decided that students would learn the processes of design and model creation.

The teachers accomplished STEAM integration at the sixth-grade level because the principal had conceptualized STEAM education as an organically blended approach from the beginning of the teacher leaders' professional development program. The school's STEAM education framework was to locate interstices among the traditional STEM disciplines as well as language arts and social studies for integration and collaboration. A language arts teacher suggested the Dragonwings book for integration in the STEM (windmill design) unit in this collaboration spirit. Second, the STEм teachers saw the overlapping topic or ideas in language arts and STEM. Third, STEM and language arts and social studies teachers found overlapping social, cultural, local, and other factors (issues) in the STEM topic. Finally, the teachers decided to engage students in STEAM interactions in both classes by leveraging contents and ideas from respective STEAM content areas.

\subsection{Analysis}

We used qualitative analysis processes based on Miles et al. (2014) to analyze our data. According to Miles, Huberman, and Saldana (2014), qualitative data 
analysis first requires the researchers to read the transcripts, field notes, and artifacts to read these data carefully and line-by-line generating broad and specific codes based on the questions to be answered and the theories of the study. So, we first developed open codes and memos specifically focusing on critical consciousness, empowerment, race, immigration, local concerns, change, science, mathematics, and related areas. The first author independently coded the data and generated a total of 36 codes. These codes were shared with a researcher and 24 codes were considered relevant to the study based on consensus. Some of the 24 codes were: "immigrants like Chinese, Hmong, Mexican;" "cultural stereotype - low ability, not knowing English;" "windmill and wings made by Windrider;" "eviction of Chinese immigrants:" "Mexican immigrants not finding a rental home;" "windmill and environmental issues;" "family separation;" "family support;" "family resiliency;" and "economic challenge of engineering." These 24 codes were then collapsed into larger codes based on similarities in the themes producing 8 codes. These 8 codes were then collapsed into three themes as findings. We used memos to connect codes to build a more intelligible larger code and a final theme (finding) during the process (see Table 2).

TABLE 2 Coding scheme and theme generation

Codes Statements

Chinese, Hmong, Hispanic

Place to live

One family two places

STEAM and consciousness
Chinese and Hmong are hardly seen in our community

We have more "Mexican" in the meatpacking You know we have seen so many of our friends moving from apartment to next apartment. She wasn't given the room because the family couldn't speak English well ...

We have "Juan" and "Felicia" cousins [who] now live four blocks apart ... because of the job

I wish there [were] fewer stops so they can reach school on time.... you know the rate of moving like in windmill ... so less time. I wish there [were] fewer stops so they can go school on time.... you know the rate of moving like in windmill ... so less time. 
TABLE 2 Coding scheme and theme generation (cont.)

Larger Codes based on above codes

Family Separation

STEAM content understanding
Memo: Housing and language discrimination makes attending school challenging We have more "Mexican" in the meatpacking Public transportation and number of stops makes attending school difficult for immigrant families with no transportation ... Like faster means less stop ... you distance and time. Family gets separated when they have to travel.

We get stressed and so feels like bound to unrelated places with cousins in some other place ... wish they had [another] way to get faster to my [cousins'] apartment....

Theme (Findings)

Divided Family (ruptured Family) Memo: Students are able to connect public transportation, economic and social issue[s] with their learning in STEAM class. Also, students see the disparities as binding and not liberating

We present three findings that show how STEAM education could be leveraged to engage students in critical consciousness and build social action and personal transformation capacity. The three themes are: STEAM education as empowering and liberatory, resiliency in STEAM learning, and critical race consciousness in STEAM learning. We present the findings to show how STEAM education could provide spaces for liberatory and transformative engagement 
opportunities and build critical consciousness and empowerment. The focus of the two research questions is overlapping and complementary. Therefore the findings (themes) are presented to answer both the questions simultaneously rather than separately. We have made minor edits to the students' and teachers' comments and conversations for clarity purposes in the findings and discussions sections.

\subsection{Ruptured Families: STEAM Content as Empowering and Liberatory}

We continuously observed a common theme among students in Mrs. B's language arts class and Mrs. H's science class. These themes included: families, economy, and support systems. These common themes were illustrated during the following exchanges:

Mrs B:

Students 1

(girl, Hmong):

Student 3 (girl, White):

Student 8 (boy, Hispanic):

Student 24 (girl, White):

Student 9 (boy, White):
What makes Windrider and Moon Shadow's success? There is a lot of support from family, like uncles [of Moon Shadow] and cousins ... even like sending money to China to help family ... ... they kept trying to make the wings ... failed, and still son, father, uncle,... all pitched in ... ... I don't know if Windrider had succeeded in making the pair of wings without family helping ... financial support from Moon Shadow by looking after the shop ... and uncles of Moon Shadow sharing rent ... this is how Windrider got help ...

They [Windrider] had very little money to buy the material for wings ... they [Windrider] also struggled to pay rent ... so family like uncle was helpful.

The above discussion illustrates that Windrider successfully flew because of his family's support and persistence of the father and the son in the task.

In the science class, students were figuring out different aspects of a windmill and trying them out to get the best results. The groups worked as a family (team) to get the design work.

\footnotetext{
Student 9 ... Our team members are like our families. We need (boy, White): to work together and find a way to make the rotors work ...

Student 1 ... we need to think about ... how much to spend ... (girl, Hmong): $\quad$ budgeting in the family is important....
} 
In another group,

Student $14 \quad$ Guys, let's decide if we can buy a different material (boy, Non-White): for the rotor.

Student 18 Can we exchange with another group? Because we (boy, White): don't have funds to buy a new set of rotor material.

Another group had challenges deciding whether the science behind the materials they chose could be ascertained without testing.

Student $14 \quad$ When we buy the material, we can test. We have to (boy, Non-White): test here [at their work table], and if doesn't work, we'll have very little money left.

Similarly, in another group, a student said

Student $11 \quad$ We need to think about helping us all. We can't just (girl, White): $\quad$ spend, but Nancy thinks that we should buy all ... I think if we [can] do with less, why not.

In all of these interactions, students continuously weighed the team's goal to build a windmill that benefited many without disrupting the team cohesion despite differing ideas. So the selection of rotor material, plastic spokes to hold rotor on the frame, glue sticks, and many other needs were based on bringing the team together for a common cause. The students showed a new way to save money and spend on different windmill materials they might need later.

In the language arts class with Mrs. B, students drew from their science class experiences building a windmill prototype. One group discussed how disruption in the family in two different countries, the U.S. and China, created cultural and financial upheavals.

Student 19 The conviction and desire of Windrider to build (girl, White): $\quad$ wings to fly [united] his son, uncle, and other family members.

In another group, students discussed,

Student 18 It's the designing the wings and seeking help from a (boy, White): $\quad$ White landlady to write a letter to the Wright brothers was bringing family together 
In the third group, the first author (researcher) asked students,

Researcher: How did making the wings to fly by the father [Windrider] help the son [Moon Shadow] and others? Student 4 Just like we came together in our group to make wind(girl, Hmong): mill in science.... Family is what we[Hmong] rely on and [what] keeps us feel supported

Student $6 \quad$ We had different ideas about the rotor, but the cause (girl, Hispanic): $\quad$ was to getting it right ... without my family I won't be here. We depend and send money back home.

Student 9 We had to balance the funds we had with what we (boy, White): needed to build our windmill and Windrider supporting his elderly mother in China and building the wings for him to fly was like we deciding which parts for the windmill we don't buy or change.

Students' comments indicated their reflections on how teams or families made choices that benefitted most family members. There were issues of economy, goal setting, family responsibility to accomplish the goal that aided most group members. Students showed linkages between their language arts class and STEM class and drew on the value of family or group support to succeed in designing and building a windmill. Students showed a sense of critical consciousness by linking persistence in STEM tasks to family support despite failures. The students made connections between schoolwork and their understanding of the importance of family support. Thus, students linking personal experiences with STEAM education is about both empowerment and liberation in that they extended STEAM learning to their home experiences.

The ST ЕАм framework allowed students and the teachers to draw from language arts and science areas to engage students in a windmill activity. Space for the STEAM content areas and social and economic issues based on their contextual realities allowed students to understand oppressed people's struggles better. Both the classrooms had environments for students to be critical reflectors and realistic about their predicaments.

\subsection{Resiliency in STEAM Learning: A Potential Path to Empowerment and Transformation}

Emphasis on resiliency and not letting a failure disrupt an ultimate goal to achieve personal and social change is the desired outcome of STEAM education. The idea of empowerment rests on recognizing challenges in a local context and potentially seeking a solution. Therefore, resiliency and the ways 
people in a community find means to cope with challenging social issues are empowering acts. The sixth-grade class observations and conversations with students showed critical awareness among students that the local context was crucial to resiliency and personal empowerment. The windmill activity was chosen because it connected to the local community and industries that received a part of their electrical energy from the nearby windmill farm. Also, adults in students' families worked in many of these factories, experiencing challenges because of their immigrant and refugee status.

In the language arts class, Mrs. B asked students to think about how "Windrider, Moon Shadow, and other local Chinese community members showed resiliency to get Windrider to fly." Students' arguments showed their understanding of the Chinese community's resiliency at that time. They extended that to their own family and community experiences and how they found empowerment through local and personal resources.

Student 2:

(girl, White)

Student 12:

(girl, Hispanic)

Student 8:

(boy, Hispanic)

Student 14:

(boy, Non-White)
The Windrider failed more than a dozen times but still kept going.... We failed when making the windmill rotor but kept going ... like our friends who are learning English but fluent in Hmong and Spanish keep learning ... it's like you find a local solution.

Moon Shadow and his uncle wanted to give up but later considered it the 'Chinese pride' to carry on.... When you leave your place like our friends from Mexico, Sudan, Hmong, you have no choice ... our family found a food bank, free health center, ... my mom and others from El Salvador, Sudan, take [adult] English class ...

They left China and are in the U.S., they can't leave, so they have to keep trying.... Look at our friends, parents, and uncles and brothers who work in meatpacking plants ... working for [the] family to succeed [in] ... learn English in [the] evening [at the adult language program for immigrants] ...

It would be sad if Windrider gave up because it would be a bad example for his son [Moon Shadow].... Immigrants are resilient ... that's how we succeed ... my parents are learning English and learning to help other parents ... 
Students drew from the concept of resiliency, an integral part of success despite hardships. Resiliency was contextual to their friends and community, specifically among immigrant and refugee families. Student 2, Student 8, and Student 14's comments show that resiliency is a way to empower them from the challenges of being an immigrant and provide a sense of agency to succeed. They also seemed to find a sense of empowerment from their home experiences that helped in their STEAM education activities and learning. Additionally, students shared how their families were finding resources to be independent by learning English and finding food pantries. These actions are empowering, transformative, and liberatory for the immigrant families allowing them to take steps that fit their needs.

This discussion in language arts class spilled over into Mrs. H's science class during the last stages of completing their design. One group was trying to figure out why a low-weight rotor was working better in high wind speed but would breakdown in low wind speed. In science class, they had learned how mass influenced rotational speed, and rotational speed was connected to the thickness of the rotor material. They understood thickness of the rotor material was proportional to the speed of rotor movement and the amount of electricity generated.

$\begin{array}{ll}\begin{array}{l}\text { Student } 5 \\ \text { (girl, White): }\end{array} & \begin{array}{l}\text { I'm really frustrated, but I can't give up because we } \\ \text { have come so far.... We know rotor speed is propor- } \\ \text { tional to wind speed, ... but it's not working here ... } \\ \text { our backyard windmill sometimes not turning ... }\end{array} \\ \text { Student } 3 & \begin{array}{l}\text { Yes. I have seen the big wind farm rotors not turning } \\ \text { in high wind.... This reminds me [of] Windrider and }\end{array} \\ & \begin{array}{l}\text { Moon Shadow.... We just have to try.... Maybe rotor } \\ \text { speed is proportional to a certain wind speed. }\end{array} \\ \text { Student } 7 & \begin{array}{l}\text { Let's put a sign like "Do NOT operate at a very low } \\ \text { (girl, White): }\end{array} \\ & \begin{array}{l}\text { speed.”... we sometimes see our farm windmills not } \\ \text { turning [despite] strong wind. }\end{array}\end{array}$

The group got the idea for their solution because they had seen that the local windmills do not run during certain wind conditions, even when the wind is blowing at low speed or high speed. Students brought local experiences and solved the problem they faced. We find this an empowering experience for students because it was their solution based on their experiential knowledge.

Similarly, another group struggled to figure out how to hold the rotors in place because they had chosen thick material to catch the high wind. They 
had tried adding reinforcements by gluing the turbine's shaft, but the rotor still only worked in very high wind speed conditions. They asked another group that had a similar problem earlier. The group's resolution was "reducing the number of supports" used to hold the rotor. This lightened the rotor, and it worked but could not operate at a medium wind speed. The first author asked them, "How did you get this done?" The students said:

Student 12: It was all about to keep trying and asking if wind speed (girl, Hispanic) and rotor speed are really connected [proportional].... We found help from another group ... that we lighten it by removing some supports from the rotor.... I was about to give up and get a low grade.

Student 13: $\quad$ We wanted to give up, and we all thought if Windrider (boy, White) can do it, then we can, too.... Because they did it even when San Francisco had the earthquake, and they [Chinese immigrants] all lost everything.

The reflection and connection between the lives of the characters in Dragonwings and students' classroom ups and downs while building a windmill showed their understanding of resiliency and empowerment. We also found that students felt empowered and had transformative experiences from the Dragonwings story to create a workable windmill despite many technical challenges. This seemed like a STEAM education outcome, where engagement in language arts class intersected with science class and an engineering design activity, empowering students to broaden their STEAM learning beyond classroom activities and lessons.

\subsection{Advancing Critical Race Consciousness in STEAM Learning: A Sense of Liberation}

This theme is the sole product of the book, Dragonwings. In this science classroom, instruction was built around the discussions of race, discrimination, social justice, liberation, and diversity, unlike many STEM or STEAM classrooms where this kind of discussion is still a struggle. According to LSP, questioning the status quo and challenging discriminatory practices are parts of the idea of liberation. Liberation and critical consciousness are interconnected because liberatory actions and activities do not happen without critical consciousness. Thus, STEAM classrooms potentially generate atmospheres for students to be critically conscious about science content such as energy and windmill that have direct social, racial, and economic implications on many 
underrepresented families. In this class, we observed and listened to students talking about race and discrimination endured by immigrant communities. Students also found critical consciousness and liberation ideas linked to science and engineering activities in the science class.

During the language arts class, students critically reflected on the racism and prejudice endured by Chinese immigrants in the early 19oos. They linked Chinese experiences with their immigrant friends' and families' experiences coping with discrimination in jobs, education, and language. With a prompt from Mrs. B, the students drew racial parallels between Chinese immigrants' experiences during the 1906 San Francisco earthquake and current Hispanic and other immigrant groups' struggles in their community.

\begin{tabular}{|c|c|}
\hline $\begin{array}{l}\text { Student 3: } \\
\text { (girl, White) }\end{array}$ & $\begin{array}{l}\text { Earthquake and tornadoes and floods don't care } \\
\text { about people, but what we [White majority] choose } \\
\text { to do and to which group is different.... I think it's very } \\
\text { discriminating.... Mostly refugees like Hmongs and } \\
\text { immigrants like [Hispanic] don't get help. }\end{array}$ \\
\hline $\begin{array}{l}\text { Student 14: } \\
\text { (boy, Non-White) }\end{array}$ & $\begin{array}{l}\text { You know in earthquake only White people got all the } \\
\text { things like rescued from house fire and [pulled out } \\
\text { from] rubble, ... Chinese immigrants didn't... They } \\
\text { lost lives, and nobody helped. }\end{array}$ \\
\hline $\begin{array}{l}\text { Student 6: } \\
\text { (girl, Hispanic) }\end{array}$ & $\begin{array}{l}\text { The gas lamps were for White people, not for Chinese.... } \\
\text { So is the windmill farm near us the same way? }\end{array}$ \\
\hline
\end{tabular}

We observed that students supported their arguments related to discrimination, racism, and social justice based on scientific ideas they had learned.

\begin{tabular}{|c|c|}
\hline $\begin{array}{l}\text { Student 14: } \\
\text { (boy, Non-White) }\end{array}$ & $\begin{array}{l}\text { San Francisco falls along [the] Pacific Ring of Fire, an } \\
\text { earthquake [prone] region, so homes were not built } \\
\text { to [stand] up in a strong earthquake.... Blaming immi- } \\
\text { grants is just wrong. Chinese immigrants [should } \\
\text { have] asked landlords to make better homes ... } \\
\text { couldn't they pay [rent] when they lost personal } \\
\text { [valuables] in earthquake ... }\end{array}$ \\
\hline $\begin{array}{l}\text { udent 3: } \\
\text { irl, White) }\end{array}$ & $\begin{array}{l}\text { If you have gas lines and it breaks, fire is obvious ... no } \\
\text { fire-resistance materials with wooden homes. I think } \\
\text { the immigrants [Windrider] asked for shelter from } \\
\text { the landlady ... his family didn't get any [break] from } \\
\text { rent or place to sleep ... }\end{array}$ \\
\hline
\end{tabular}


Student 5: Earthquake is not an immigrant family's fault ... so (girl, White) why should they pay rent ... may be demand free living for one or two months ... you know you pay rent in advance ...

In these statements, students critically reflected on local issues of racism, discrimination, and their sense of the right thing to do. The students knew the science of earthquakes, but they questioned the disproportionate effects of these events on racial minorities (Chinese immigrants) because of prejudice. We also noticed potential liberatory ideas and actions that students advocated for immigrants who paid rent but did not have any recourse to get their money back after the earthquake. Also, they suggested possible action such as not paying rent until the living conditions were made right.

In Mrs. H's class, students examined their windmill activity. They reflected on who benefited from developing windmill farms in their community. Even though the idea of renewable energy, harnessing wind energy into electrical, seemed valuable, students were not sure about the direction of the benefits. In science class, groups presented each design and shared the benefits of windmills for their community year-round. However, three groups asked the question, "Who benefits from the windmill, and would Hmong and Hispanic families get the benefit, too?" In each case, the groups shared statements like:

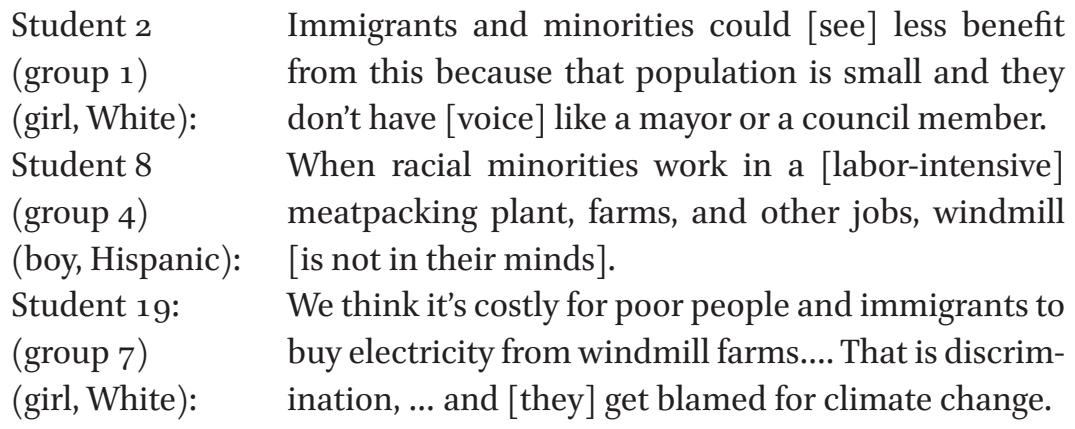

Students seemed to show concern for underrepresented groups in their communities for not having much say in community decisions. The sixth-grade students were aware that science could help them advocate against discrimination and racial disparities. The combination of language arts and science class comments illustrates that STEAM education provided an environment for students and supported by their teachers to critically exploring race, prejudice, and discrimination in the context of a STEAM activity. 


\section{Discussions and Implications}

Our view of STEAM education is beyond integration of content areas and engaging students in engineering activities. We believe STEAM education's purposes have to be more than 21st-century skills development, economic gain, and content mastery. STEAM education has to provide opportunities and spaces to students, specifically those from underrepresented groups and girls, to critically reflect and challenge existing social structures of oppression and subjugation. Studies in science education have clearly shown that when given space and environment to leverage science to explore socioculturally related issues, students seem to show more significant affinity to science and are more engaged (Arnold \& Clarke, 2014; Bruna, 2009; Osborne \& Calabrese Barton, 1998; Tal, 2020; Upadhyay \& Albrecht, 2011; Upadhyay et al., 2020).

All students are capable of learning science for a better future. Students are also competent to connect social issues in STEAM learning. In this study, sixth graders utilized an engineering-design team activity to collectively seek a solution that had multiple factors to complete the windmill successfully. Drawing from the lessons based on Windrider and Moon Shadow's characters, students successfully kept the windmill activity on track. The exchanges between students showed the potential benefits of linking language arts with science and engineering. Literature lessons and the windmill activity had overlapping themes of team-building intending to accomplish a meaningful task. Just like Windrider and Moon Shadow felt flying was part of their core identity, students also took building a windmill within given constraints as their core identity.

One of the core values noted by STEM or STEAM education advocates has been to support integrated design-focused science instruction to develop attitudes and habits like learning from failure, persistence, and productive failure (Henriksen, 2014; Kelley \& Knowles, 2016; Jonassen et al., 2006; National Research Council, 2013). These values are essential for learning as well as success in STEAM education, but only when the values and beliefs align with dominant values and beliefs. For many underrepresented groups, critically examining status quo values and mindsets like persistence and productive failure means building resiliency as a core value. Underrepresented groups encounter barriers to learning in multiple ways that can only be overcome through resiliency. Therefore, learning in a STEAM education environment for social change and personal transformation should also build a resilient attitude and value. Resiliency "interventions should target protective and vulnerability forces at multiple levels of influence - culture, community, family and 
the individual" (Cicchetti, 2010, p. 151). In this study, we find students continuously state their struggles with phrases like "not give up," "can't give up," "try," and "resilient," indicating that they are resilient and value resiliency more than just learning from failure. The study showed that students connected Hmong, Hispanic, and other immigrants' discriminatory experiences in their community with Chinese immigrants' lived experiences in the early 19oos. Another aspect of resiliency is how much STEAM education is connected to immigrant and refugee students' sociocultural knowledge and values (Ryu \& Daniel, 2020; Upadhyay, 2009). The stronger the sociocultural connections (Adams, 2020) to STEAM, the more meaningful learning marginalized students tend to have in everyday classrooms (Upadhyay, 2006; Upadhyay et al., 2020).

In this study, students showed potential actions for liberation from discrimination through resiliency, critical consciousness, and leveraging science and engineering ideas. Our analysis of the data showed limited opportunities for students to explore and connect STEAM activities to liberation ideas. Even though the classroom demographic had overwhelmingly White students, we firmly believe that White students were equally engaged in questioning and pushing against the existing racial and discriminatory social experiences of underrepresented groups. The demographic imperatives in a global society are that immigrants are present in many countries. Generally, most immigrants and cultural minorities experience many kinds of discrimination and oppression because of the dominant group's policies and practices. For socially just, liberatory, and empowering STEAM education learning, White students in this class critically reflected, explored, challenged, discussed, and recognized racial and other discriminations existing in the community in a safe classroom environment. Without a secure environment and willing teachers, the students may not have engaged in critical consciousness discussions about race and social justice. However, this study shows a potential opportunity STEAM education could provide students and teachers to reflect on and take actions against discriminatory social issues for a liberated society (Martín-Baró, 1996; Montero, 1996). In this regard, the concept of liberation has excellent potential in STEAM education. It can encourage students to examine racially and socially discriminatory issues through critical reflections in STEAM activities.

We have struggled to find much work in STEM and STEAM education focused on racial and ethnic discrimination to improve the experiences of underrepresented groups in STEAM (e.g., Pugh et al., 2019; Upadhyay et al., 2021b). Most scholars of Indigenous, urban, and underrepresented groups in STEM education have alerted STEM educators, policymakers, and scholars to encourage students to challenge the racialized power of STEM (e.g., Bang \& Medin, 2010; Spivak, 1988; Vossoughi \& Vakil, 2018; Upadhyay et al., 2010a). In this study, we 
observed students pushing the boundary of their STEAM activities and engagements into questioning their windmill design purposes with questions like, "Who is the product for?" and "Who gets left out of it?" Students were examining the local context based on what they have experienced around them. Their reflective discussions and critique of social issues showed real local concerns and stood in opposition to dominant ideologies that immigrants are "others." Furthermore, this study agrees with the findings of Albrecht and Upadhyay (2018) and Ryu and Daniel (2020) in that a successful steAm education for immigrant groups needs to recognize cultures, funds of knowledge, and lived experiences of these groups as assets to inform and engage in critical STEAM education. As more people from Asia-Pacific region become immigrants and refugees in new sociocultural and linguistic countries because of economic pressures, religious and political persecutions, and other discriminations, STEAM education needs to take a culturally relevant, liberatory, and sociopolitically transformative stance both in curriculum and pedagogy.

We consider STEAM education provides agency to students to interpret and make sense of their world more broadly than just completing design activities and science content learning. We agree that STEAM education should be about the "process of human change and transformation, ... [which] always entails participation in relationship and community and transformation both of the person and of the social world" (Packer \& Goicoechea, 2000, p. 239). This study indicates STEAM education should not only envision content integration, excelling on tests, and collaborative activity completion but also the value of social and personal liberation (Burton \& Kagan, 2005; Martín-Baró, 1996) and empowerment through critical reflective engagement.

As many countries are pursuing STEAM education as the critical national policy in school education improvement and modernization, Global South countries from Asia need to envision STEAM education that is locally conceptualized, designed, produced, and implemented. STEAM education should look different in its framing and its goals and values aligning with Asian nations' cultures, values, beliefs, history, and politics (Upadhyay et al., 2021b). Asian countries and groups within those countries are not monolithic. Asian countries are full of cultural, social, political, historical, linguistic, and environmental diversities; therefore, social change, liberation, critical consciousness, and personal transformation have to be central to STEAM education. STEAM education cannot just address more people graduating with STEAM degrees. More importantly, it has to uplift oppressed groups by building critical consciousness, liberation, and social and personal transformation leveraging STEAM fields. 


\begin{abstract}
Abbreviations
LSP Liberation Social Psychology

STEAM Science Technology Engineer Arts Mathematics

STEM Science Technology Engineer Mathematics
\end{abstract}

\title{
Ethical Consideration
}

Approval to conduct this study was granted by the University of Minnesota Ethics Review Board. The data collected from this project were obtained with the necessary clearance from the partner institutions, guardians, and the students involved in the study. The names of the school and participants used in this study are all pseudonyms.

\section{About the Authors}

Bhaskar Upadhyay is an associate professor and the program area coordinator of STEM and Science Education at the University of Minnesota. Dr. Upadhyay's research focuses on improving STEM teaching, learning, and engagement for students, teachers, and parents from marginalized and Indigenous communities. He is currently leading the design and development of a high school citizen science curriculum and an indigenous ST EM teacher development program in Nepal. Currently, he is an Executive Board Member of NARST, a global organization for improving science education through research, and the chair of Indigenous Science Knowledge Research Interest Group in NARST. He is coediting a book with Dr. Femi S. Otulaja and Dr. Pauline Chinn titled "Stories for sustainable and Resilient communities: STEM education from Indigenous perspectives" to be published by Dio Press later this year.

Kara Coffino serves in a dual role at Colorado State University as Co-Director of the Center for Educator Preparation and assistant professor in the School of Education. Dr. Coffino's leadership and scholarship focus on creating pathways to teaching and diversifying the teaching force.

John Alberts is the Executive Director of Educational Services for Austin Public Schools in Austin, Minnesota. In this role, he is responsible for oversight of teaching and learning, staff development, gifted programs, English learner programs, integration programming, technology services, and federal funds. 
He is a board member of the Southeastern Minnesota Performance Excellence Network (PEN). He is the co-chair of an annual Gifted and Talented Education Symposium. He was named the Austin Education Association Teacher of The Year in 2005 and nominated as the 23 rising alumni of the University of Minnesota's College of Education and Human Development (CEHD) 23. He received the Karl Shurson Quality Award by PEN in 2018 for his work in the Gifted and Talented areas.

Andrew Rummel is a Digital Learning Coordinator for the Bloomington Public Schools. His work explores technology integration, teacher professional development, digital literacies, and online teaching and learning. Currently, he is a doctoral candidate in the Curriculum and Instruction program at the University of Minnesota. His dissertation focuses on disciplinary and digital literacies.

\section{References}

Adams, J. D. (2020). Designing Frameworks for Authentic Equity in Science Teaching and Learning: Informal Learning Environments and Teacher Education for STEM, Asia-Pacific Science Education, 6(2), 456-479. https://doi.org/10.1163/2364 1177-BJA1oo16.

Albrecht, N. \& Upadhyay, B. (2018). What do refugee mothers want in U.S. school science: Learning from the perceptions of science of three Somali mothers. The Urban Review, 5o, 604-629. https://doi.org/10.1007/s11256-018-0458-9.

Arnold, J., \& Clarke, D. J. (2014). What is 'agency'? Perspectives in science education research. International Journal of Science Education, 36(5), 735-754. https://doi.org/ 10.1080/09500693.2013.825066.

Bang, M., \& Medin, D. (2010). Cultural processes in science education: Supporting the navigation of multiple epistemologies. Science Education, 94(6), 1008-1026. https:// doi.org/10.1002/sce.

Belbase, S. (2019). STEAM education initiatives in Nepal. The STEAM Journal, 4(1). https://doi.org/10.5642/steam.20190401.07.

Bruna, K. R. (2009). Mexican immigrant transnational social capital and class transformation: Examining the role of peer mediation in insurgent science. Cultural Studies of Science Education, 5, 383-422. https://doi.org/10.1007/s11422-0o9-9232-3/.

Burton, M., \& Kagan, C. (2005). Liberation social psychology: Learning from Latin America. Journal of Community \& Applied Social Psychology, 15(1), 63-78. https:// doi.org/10.1002/casp.786. 
Bybee, R. W. (2010). What is STEM education? Science, 329(5995), 996. https://doi .org/10.1126/science.1194998.

Calabrese Barton, A. (1998). Margin and center: Intersections of homeless children, science education, and a pedagogy of liberation. Theory Into Practice, 37(4), 296-305. https://doi.org/10.1080/00405849809543819.

Calabrese Barton, A., Basu, J., Johnson, V., \& Tan, E. (2011). Introduction. In J. Basu, A. Calabrese Barton, \& E. Tan (Eds.), Democratic science teaching: Building the expertise to empower low-income minority youth science (pp. 1-20). Springer.

Carlone, H., \& Johnson, A. (2012). Unpacking 'culture' in cultural studies of science education: Cultural difference versus cultural production. Ethnography and Education, 7(2), 151-173. https://doi.org/10.1080/17457823.2012.693691.

Cicchetti, D. (2010). Resilience under conditions of extreme stress: A multilevel perspective. World Psychiatry, 9, 145-154. https://doi.org/10.1002/j.2051-5545.2010 .tboo297.x.

Cole, A. (2020). Introduction: The ideology issue. The South Atlantic Quarterly, 119(4), 667-67o. https://doi.org/10.1215/oo382876-8663554.

Cole, N. L. (2019). Theories of ideology: The concept and its relationship to Marxist Theory. Retrieved from https://www.thoughtco.com/ideology-definition-3026356.

Crotty, M. (1998). The foundations of social research. Sage Publications.

Eagleton, T. (1991). Ideology: An introduction. Verso.

Eisenhart, M., Weis, L., Allen, C. D., Cipollone, K., Stich, A., \& Dominguez, R. (2015). High school opportunities for STEM: Comparing inclusive STEM-focused and comprehensive high schools in two US cities. Journal of Research in Science Teaching, 52(6), 763-789. https://doi.org/10.1002/tea.21213.

Fanon, F. (2005). The wretched of the earth. Grove Press.

Freire, P. (1972). Pedagogy of the oppressed. Penguin.

Gramsci, A. (1971). Selections from the prison notebooks (G. N. Smith, Ed.). International Publishers.

Hallström, J., \& Ankiewicz, K. J. (2019). Models and modelling authentic STEM education: Reinforcing argument. International Journal of STEM Education, 6(22), 2-10. https://doi.org/10.1186/s40594-019-o178-z.

Henriksen, D. (2014). Full STEAM ahead: Creativity in excellent STEM teaching practices. STEAM, 1(2), 1-9. https://doi.org/10.5642/steam.20140102.15.

Jennings, T. E., \& Eichinger, J. (1999). Science education and human rights: Explorations into critical social consciousness and postmodern science instruction. International Journal of Educational Reform, 8(1), 37-44. https://doi.org/10.1177/ 105678799900800105.

Jonassen, D., Strobel, J., \& Lee, C. B. (20o6). Everyday problem solving in engineering: Lessons for engineering educators. Journal of Engineering Education, 95(2), 139-151. 
Kelley, T. R., \& Knowles, J. G. (2016). A conceptual framework for integrated STEM education. International Journal of STEM Education, 3(1), Article 11. https://doi .org/10.1186/s40594-016-0o46-z.

Kincheloe, J. (1999). Trouble ahead, trouble behind: Grounding the post-formal critique of educational psychology. In J. Kincheloe, S. Steinberg, \& P. Hinchey (Eds.), The postformal reader: Cognition and education (pp. 4-54). Falmer Press.

Kincheloe, J., \& Steinberg, S. (1993). A tentative description of post-formal thinking: The critical confrontation with cognitive theory. Harvard Educational Review, 63(2), 296-32o. https://doi.org/10.17763/haer.63.3.h423221226v18648.

Ladson-Billings, G. (1995). Toward a theory of culturally relevant pedagogy. American Educational Research Journal, 32(3), 465-491. https://doi.org/10.3102/0002831203 2003465.

Ladson-Billings, G. (2014, June). Culturally relevant pedagogy 2.o: a.k.a. the remix. Harvard Educational Review, 84(1), 74-84.

Lynn, A. B., Moore, T. J., Johnson, C. C., \& Roehrig, G. H. (2016). Integrated STEM education. In C. C. Johnson, E. E. Peters-Burton, \& T. J. Moore (Eds.), STEM road map: A framework for integrated STEM education (pp. 23-37). Routledge.

Martín-Baró, I. (1996). Writings for a liberation psychology (A. Aron \& S. Corne, Eds.). Harvard University Press.

Means, B., Wang, H., Young, V., Peter, V. L., \& Lynch, S. J. (2016). STEM-focused high schools as a strategy for enhancing readiness for postsecondary STEM programs. Journal of Research in Science Teaching, 53(5), 709-736. https://doi.org/10.1002/ tea.21313.

Merriam, S. B. (1998). Qualitative research and case study applications in education. Jossey-Bass.

Merriam, S. B. (2002). Qualitative research in practice: Examples for discussion and analysis. Jossey-Bass.

Miles, M. B., Huberman, M. A., \& Saldana, J. (2014). Qualitative data analysis: A resource book (3rd ed.). Sage.

Montero, M. (1996). Parallel lives: Community psychology in Latin America and the U.S. American Journal of Community Psychology, 24(5), 589-6o5. https://doi.org/ 10.1007/BFo2509715.

National Academy of Engineering and National Research Council. (2014). STEM integration in K-12 education: Status, prospects, and an agenda for research. The National Academies Press. https://doi.org/10.17226/18612.

National Research Council. (2013). Next generation science standards: For states, by states. The National Academies Press. https://doi.org/10.17226/1829o.

National Science Board. (2010). Science and engineering indicators 2010. National Science Foundation. 
Organisation for Economic Co-operation and Development. (2016). The OECD Learning Compass 2030. http://www.oecd.org/education/2030/.

Osborne, M. D., \& Calabrese Barton, A. M. (1998). Constructing a liberatory pedagogy in science: Dilemmas and contradictions. Journal of Curriculum Studies, 30(3), 25126o. https://doi.org/10.108o/002202798183602.

Packer, M. J., \& Goicoechea, J. (2000). Sociocultural and constructivist theories of learning: Ontology, not just epistemology. Educational Psychologist, 35(4), 227-241. https://doi.org/10.1207/S15326985EP3504_o2.

Pugh, P., McGinty, M. \& Bang, M. (2019). Relational epistemologies in land-based learning environments: reasoning about ecological systems and spatial indexing in motion. Cultural Studies of Science Education, 14(2), 425-448.

Radloff, J., \& Guzey, S. (2016). Investigating preservice STEM teacher conceptions of STEM education. Journal of Science Education \& Technology, 25, 759-774. https:// doi.org/10.1007/s10956-016-9633-5.

Ryu, M., \& Daniel, S. M. (2020). How did we engage resettled Chin youth in critical STEM literacy practices?, Asia-Pacific Science Education, 6(2), 319-345. https://doi .org/10.1163/23641177-BJA1ooo8.

Sandoval, C. (1995). New sciences: Cyborg feminism and the methodology of the oppressed. In C. H. Gray (Ed.), The cyborg handbook (pp. 407-422). Routledge.

Spivak, G. C. (1988). Can the subaltern speak? Macmillan.

Stake, R. E. (1995). The art of case study research. Sage Publications.

Sypnowich, C. (2019). Law and ideology. In E. N. Zalta (Ed.), The Stanford encyclopedia of philosophy. https://plato.stanford.edu/archives/sum2o19/entries/law-ideology/.

Tal, T. (2020). Inequity and cultural differences in out-of-school science education: The case of the Arab minority in Israel. Asia-Pacific Science Education, 6(2), 427-455. https://doi.org/10.1163/23641177-BJA1oo11.

Upadhyay, B. (2009). Teaching science for empowerment in an urban classroom: Using Hmong students' funds of knowledge. Equity and Excellence in Education, 42, $217-232$.

Upadhyay, B. (2010). Elementary school science teachers' perceptions of social justice: A study of two elementary teachers. Equity and Excellence in Education, 43, 56-71.

Upadhyay, B., \& Albrecht, N. (2011). Deliberative democracy in an urban elementary science classroom. In S. Basu, A. Calabrese Barton, E. Tan (Eds.), Building the Expertise to Empower Low-Income Minority Youth in Science (pp. 75-83). Sense.

Upadhyay, B. (2012). Elementary students' ways of seeing globalization in science. In J. Bianchini, V. Akerson, A. Calabrese Barton, O. Lee, and A. Rodriguez (Eds.), Moving the Equity Agenda Forward: Equity Research, Practice, and Policy in Science Education (pp. 99-118). Springer. 
Upadhyay, B., Atwood, E., \& Tharu, B. (2020). Actions for sociopolitical consciousness in a high school science class: A case study of ninth grade class with predominantly indigenous students. Journal of Research in Science Teaching, 57 (7), 1119-1147. DOI:10.1002/tea.21626.

Upadhyay, B., Atwood, E., \& Tharu, B. (2021a). Antiracist pedagogy in a high school science class: A case of high school science teacher in an Indigenous high school.Journal of Science Teacher Education. https://doi.org/10.1080/104656oX.2020.1869886.

Upadhyay, B., Alberts, J., Coffino, K., \& Rummel, A. (2021b). Building a successful university and school partnership for STEAM education: Lessons from the trenches. Southeast Asian Journal of STEM Education, 2(1), 127-15o. https://drive.google.com/ file/d/13h4ivT-FrSjFcSA3xLoEdRdqqvY5Ut86/view.

Upadhyay, B., \& Tharu, B. (2021, April). Building antiracist science teachers for Indigenous schools: Lessons from a science professional development workshop [Paper presentation]. National Association of Research in Science Teaching, Virtual Conference, USA.

U.S. Census Bureau. (2019). Quick facts. https://www.census.gov/quickfacts/.

Vasquez, J., Sneider, C., \& Comer, M. (2013). STEM lesson essentials, Grades 3-8: Integrating science, technology, engineering and mathematics. Heinemann.

Vossoughi, S., \& Vakil, S. (2018). Towards what ends? A critical analysis of militarism, equity and STEM education. In A. Ali \& T. L. Buenavista (Eds.), Education at war: The fight for students of color in America's public schools (pp. 117-140). Fordham University.

Watts, R. J., Williams, N. C., \& Jagers, R. J. (2003). Sociopolitical development. American Journal of Community Psychology, 31, 185-194. https://doi.org/10.1023/ A:1023091024140.

Yep, L. (2003). Dragonwings (25th ed.). Harper Collins.

Yin, R. K. (2002). Case study research: Design and methods. Sage Publications. 